\title{
O Poder Civil e a Obrigação de Consciência:
}

\section{Os Limites da Política}

\author{
Marcus P. R. Boeira*
}

RESUMO: O presente artigo expõe uma breve reflexão em torno dos limites do poder civil relativamente à consciência humana. Para tanto, propõe uma articulação entre a liberdade para ter condições de agir e a ação prático-moral, articulação esta que desponta como tipologia-padrão da razão prática, além de critério objetivo suficientemente capaz de fundamentar uma ação política legítima, distinguindo-a da ação impolítica, tomada aqui como fenômeno no qual o poder não encontra limites objetivos e se expande para invadir esferas que não lhe competem. O critério definitivo que qualifica uma ação política como ancorada na prudência é o bem comum.

Palavras-Chave: Poder; Consciência; São Tomás de Aquino; Francisco Suarez; Império da Lei
“Oboedire oportet Deo magisquam homínibus” (Act. 5, 29)
"15 qui ostendunt opus legis scriptum in cordibus suis, testimo- nium simul reddente illis conscientia ipsorum, et inter se invi- cem cogitationibus accusantibus aut etiam defendentibus, ${ }^{16}$ in die, cum iudicabit Deus occulta hominum secundum evange- lium meum per Christum Iesum” (Rm 2, 15-16)

"Nam contra rationem naturalem est dicere non posse quempiam absolvi a promissione iuramento confirmata per materiae mutationem, illam auferendo et quase irritando" (Francisco Suarez, De Iuramento Fidelitatis V 4).

\footnotetext{
* Professor de Filosofia do Direito e Lógica Jurídica na Faculdade de Direito da Universidade Federal do Rio Grande do Sul. Doutor e Mestre pela USP. Líder do Grupo de Pesquisa $\mathrm{CNPq}$ Lógica Deôntica, Linguagem e Direito. Visiting Scholar na Pontificia Università Gregoriana-Roma, onde cursou o Pós-Doutorado em Filosofia, estudando a Lógica da opinião provável em Diego de Avendaño.
} 


\section{Introdução}

O presente artigo visa apresentar algumas reflexões assistemáticas em torno da natureza do poder civil e os limites que o seu exercício deve encontrar relativamente a uma área sensível da condição humana: a consciência.

As diversas tensões existentes entre o poder civil e a consciência humana demonstram que o tema em questão não apenas desponta com forte impacto em momentos de crise institucional e de ameaça à liberdade e à democracia, mas dá vazão ao diálogo em torno dos limites naturais da política.

A ontologia política, área destinada a perscrutar a essência do político, suas bases e postulados constitutivos, é aqui solicitada para ofertar feixes de luz sobre uma aporia de indiscutível relevância: qual o limite do exercício do poder relativamente à consciência individual? Até onde o poder civil pode ir para coagir o ser humano a violar sua própria consciência?

Eventuais respostas sobre estas fronteiras nos colocam perante um auditório exaustivo de participantes, um espaço público rico e complexo, em que as várias correntes ideológicas buscam participar ativamente para lançar suas próprias visões de mundo sobre a zona cinzenta das dúvidas e incertezas quanto aos limites do poder. A pluralidade de respostas revela algo mais profundo: o de que nossas sociedades ocidentais são marcadas por um forte dissenso, por fatores de clivagem que, não obstante os frágeis consensos formais sobre a existência de regras mínimas de convívio e de instituições juspolíticas para mediar a existência comum, podem representar, para alguns indivíduos e grupos, riscos iminentes para suas respectivas formas de vida e de crença.

A amplitude de uma visão política dentro do político, aqui tomado como fenômeno social, é uma situação que requer atenção. Há, na democracia, um espaço considerável para a formalidade. Um conjunto de exigências formais e instrumentais, cuja satisfação é imperativa para a continuidade mesma da democracia no Estado de Direito. Domesticar a democracia e o Estado de Direito são primados imprescindíveis para qualquer sociedade política que pretenda preservar certas liberdades e direitos individuais, sem os quais a ordem converte-se em arbítrio, vontade da maioria, ausência de padrões, falta de limites, tirania de uns sobre outros, em suma, naquilo que o Império do Direito pretende evitar.

\section{Política e mundo da vida}

Por certo, toda visão ideológica de mundo - por sua própria definiçãopretende lançar uma plataforma de objetivos, compromissos institucionais e reivindicações estético-morais sobre a sociedade política. Busca abranger a totalidade do mundo da vida, como também atribuir um sentido ideologica- 
mente engajado sobre o que o poder é e o que deveria perseguir. O exercício do poder político passa a ser visto aqui como movimento de expansão, destinado a tornar a visão de mundo vitoriosa em uma eleição a própria "visão de mundo" de toda a coletividade. A sociedade é artificialmente substituída por uma imagem fictícia sobre o que ela deveria ser perante a conjuntura de valores que orienta a cosmovisão reinante. Entre a sociedade real e a sociedade imaginada, esta—e não aquela—é selecionada como a imagem permanente do mundo público a ser alcançado. O poder, como também seus usos e dispositivos, é destinado a convidar-quando não coagir - os seres humanos a comportarem-se em conformidade com as pautas standards da visão de mundo adotada como a "verdade" política.

Para além das fronteiras da ação humana, o livre convencimento dos outros e, quando não, a coação pura e simples, irrompe como característica singular desta concepção de esfera pública, onde as táticas e estratégias são dirigidas não só para atrair os players, mas para decifrar os inimigos do establishment, os que, frente ao aumento progressivo do poder, procuram preservar alguns direitos e faculdades mínimos para a própria sobrevivência, como o direito a ter direitos ${ }^{1}$ e as liberdades civis.

Entre o ser humano concreto, de carne e osso, e a imagem virtual, privilegia-se a última. O novo membro da sociedade artificial, inteiramente imperiosa para a modulação dos atos humanos e das expectativas sociais, é adestrado pari passu, movendo-se para o futuro sem uma sólida estrutura mental e psíquica, sem consciência de que a causa das mudanças na cultura social é também causa da profunda transformação em sua personalidade e em seu caráter. Até mesmo o passado passa a ser seletivamente reescrito, para substituir a memória da história por uma nova descrição do estado-decoisas presente nas fontes da historiografia, uma narrativa que expressa novos sentidos em sintonia com o "espírito do tempo".

Há, de fato, uma pretensão universal nas estruturas de poder, uma inclinação imagética para a totalidade. $\mathrm{O}$ alargamento autônomo da política para além de si mesma encontra a resistência inexorável dos instrumentos, das formas e das morfologias institucionais criadas pelo ser humano e pelos grupos e movimentos sociais para a própria preservação em um ambiente crescentemente hostil e de profundas transformações. Como área de permanente tensão, a política requer limites, fronteiras necessárias para sua própria conservação e identidade comum. Normalmente, as correntes ideológicas que pleiteiam o alargamento da política, convergem em um ponto: na visão de que o poder, como fenômeno social, coincide com o que o verbo designa: a ausência de limites e a tendência natural ao crescimento.

${ }^{1}$ Expressão cunhada por Hannah Arendt. 
Quando governos valem-se de instrumentos da política para estender suas concepções acerca do que a política deveria ser, atravessam uma fronteira sensível, incorporando em suas pretensões a política do "poder". Neste caso, os mesmos instrumentos da política não passam a ser tomados como meios disponíveis para o uso arbitrário dos envolvidos na luta política. Decerto, o Estado de Direito oferece barreiras consistentes para a tirania e a impolítica. Todavia, não é por si só capaz de vencer os adversários da liberdade, vez que a democracia requer, para sua conservação, uma tábua mínima de axiomas comuns, um pavimento substancial de princípios necessários para o convívio e manutenção da própria existência social. Até mesmo o dissenso social e os fatores de clivagem só são viáveis quando o assoalho da participação e da deliberação popular solicita aos participantes o dever republicano de favorecer a "palavra do outro", a voz do diferente, a participação do oponente como parte fundamental do jogo democrático. A aproximação ou o distanciamento entre a democracia real e a democracia ideal dependerá do modo como a igualdade política, o reconhecimento do outro e a perpetuidade da liberdade civil e política constituir-se-ão como postulados inalteráveis, como fatias integrantes da ordem social.

Ver-se no outro como a si próprio ${ }^{2}$, como a outra parte que comigo forma a unidade comum é uma exigência mínima para a ordem democrática. Não há poder do povo, pelo povo e para o povo sem que no "povo" as partes não se reconheçam mutuamente como partícipes igualmente considerados no processo político.

O pavimento substancial é uma exigência material para a democracia. Nela, as instituições privadas e os movimentos sociais são organizações intermediárias imprescindíveis para a preservação das liberdades civis, para a defesa de uma área estranha ao poder político: a consciência humana.

Há, aqui, um traço paradoxal entre o poder e a consciência: se o poder conter-se e não invadi-la, preserva-a e preserva a si mesmo. Se procurar invadi-la para tomá-la de assalto, então o poder foi além de sua natural condição e, assim, destrói a si próprio.

A conservação do político requer a custódia da dignidade humana. Só há política porque os seres humanos estabelecem entre si relações variadas de mútua dependência, vínculos cruciais para o florescimento de cada um individualmente e, simultaneamente, da sociedade como um todo. Logo, a simbiose entre o EU e o NÓS, só é autêntica quando o NÓS preserva o que no EU não lhe pertence. Ou seja, entre a parte comum que está no EU e a parte privada que está em cada um de NÓS, reside uma linha demarcatória, imprescindível para que o EU não destrua o NÓS, e o NÓS não devaste a interioridade do EU.

2 Paul Ricoeur, O si-mesmo como outro, 1. ed. (São Paulo: Martins Fontes), 2014. 


\section{Liberdade de agir e liberdade para ter condições de agir}

Entre o Direito e o desacordo reside uma zona de penumbra, em que os instrumentos da política, quando bem empregados, resistem bravamente ao arbítrio.

A totalização do mundo da vida por iniciativas dominantes é uma marca clara de projetos políticos que buscam, em maior ou menor medida, destruir em parte ou inteiramente a ontologia do político.

A tarefa pedagógica do agir político que, pautado em certos valores diretores, emana uma determinada forma de vida social, pode ser vista como causa exemplar próxima da ação política. Há grandes vínculos entre a educação e a pólis, já ensinava Platão. A ordem é um traço distintivo, quase evidente, um telos compartilhado entre as sociedades humanas. A tendência histórica para uma forma de existência radicada em uma determinada concepção sobre como devemos agir ou, por outro lado, qual o motivo pelo qual uma conduta é reprovável, demonstra que as relações humanas são necessariamente pautadas por determinados axiomas que transcendem a mera vontade arbitrária ou o desejo.

A estabilização das relações humanas é desejável e cognoscível porque compartilhamos bens, estimamos certos estados-de-coisas e rejeitamos outros segundo uma forma básica de existência que a razão conhece e apreende. Esta noção epistemológica compartida sobre o que é a ordem e o motivo pelo qual devemos persegui-la conduz os agentes históricos a articular as ações individuais e os projetos coletivos de um modo inteligível para todos, oportunizando aos concordes a adesão e aos discordes o rechaço. Entre o acordo e o desacordo soerguem-se expectativas, previsões, gestão de riscos, estratégias, metodologias e procedimentos voltados para obtenção de vantagens institucionais e competitivas, ante a escassez de provisões materiais e artificiais: (i) materiais porque o acesso aos bens escassos dependerá da maneira como a economia política será assimilada pelos agentes públicos; (ii) artificiais porque é impossível que a totalidade dos seres humanos possa participar simultaneamente de todo o engenho coletivo, de toda a criação que o espírito humano foi e é capaz de empreender ao longo da história, motivo pelo qual os incentivos públicos e privados despontam como more geometrico do equilíbrio social.

As diversas tentativas de mecanizar a dinâmica social mediante fórmulas frígidas, voltadas para a previsibilidade dos acontecimentos, teve sempre como contraponto a crença forte na naturalidade do convívio social, uma crença que, apesar da fé na espontaneidade habitual, partia de um símbolo opaco, a saber, o conceito de ordem espontânea, para então supor analiticamente uma variedade de vocábulos políticos igualmente polissêmicos, co- 
mo a origem das cidades, a natureza do Estado e a organização racional dos bens públicos e privados.

A despeito da polivalência de cada tendência ideológica contemporânea, o aumento progressivo do poder como um fenômeno civilizatório contrasta com os limites naturais que o próprio poder enfrenta. Um projeto será mais eficaz tanto quanto tenha a habilidade de transigir seus respectivos princípios duros, comprometendo sua própria origem ideológica para avançar em meio aos contrastes extemporâneos. A história é uma história da existência social e política não porque a política e a sociedade constituam-se como as mais importantes ciências da humanidade (de fato não o são), mas justamente porque os contrastes e as tensões subjacentes aos desacordos nascem de uma tensão anterior, uma contradição de fundo, entre a previsibilidade e a imprevisibilidade: entre os que alcançam a posição privilegiada de delinear os acontecimentos e moldá-los segundo uma direção razoavelmente consciente, e os que imergem no horizonte de futuro sem atingir níveis de consciência capazes de explicitar a direção dos atos humanos e a abstenção de certos comportamentos.

Entre o poder e o dever reside o "motivo". Quando nos perguntamos a razão pela qual devemos agir de um dado modo, solicitamos aos artífices da ordem que apresentem as justificativas, os motivos que fundamentam as obrigações e proibições.

Em um regime impolítico, a proibição de perguntar constitui-se como um dos postulados dominantes, precisamente porque o ato de solicitar as razões é um ato que torna alguém participe do poder, um membro efetivo da comunidade política. Reivindicar uma razão para a ação é exigir que qualquer limitação à minha liberdade deve ser justificada.

Assim, há uma distinção entre liberdade de agir e liberdade para ter condições de agir: no primeiro caso, estamos diante de uma situação em que o que age, o faz porque alguém não lhe ofertou empecilhos. A maior parte das linhas contemporâneas que caracterizam o liberalismo político parte desta noção de liberdade para erigir suas respectivas teorias sobre a sociedade. A liberdade para ter condições de agir, por outro lado, impele o agente a justificar o motivo de sua ação, como também a reivindicar de quem lhe opõe restrições o porquê o faz. Ter condições para agir significa que a opção para agir e a forma da ação pertencem ambas ao meu juízo. Uma ação livre não é apenas aquela sobre a qual não recai uma intervenção externa, mas, sobretudo, aquela onde a deliberação que precede a decisão é igualmente livre e tem como autoridade não uma voz externa, mas a própria consciência interior.

Logo, seguir uma regra ou pautar a própria conduta em matérias morais ou estéticas não é algo que torne o agente dependente de uma autoridade política ou que o condicione a agir segundo padrões pré-definidos, mas é 
algo que nasce atrelado ao próprio agente que, para tal, convida a consciência a participar do julgamento, na qualidade de juíza de última instância.

Isto não quer dizer, obviamente, que uma decisão consciente não deve ter limites externos. A distinção semântica entre as expressões freedom e liberty na língua inglesa está em que a primeira implica em uma ação sem obstáculos, ao passo que a segunda, uma ação responsável. Logo, agir segundo a consciência tem como contraponto a "responsabilidade". Quem é livre para ter condições de deliberar sobre a própria ação tem, igualmente, capacidade judicativa para conhecer as consequências da própria ação, o que o conduz a refletir sobre o significado próprio e o significado compartilhado da ação que realiza.

A liberdade para ter condições de agir é, assim, uma ação pautada por três exigências: (i) responsabilidade: o dever de contemplar previamente a própria ação e suas consequências; (ii) condição real para agir de um modo determinado, tendo em vista objetivos claros e coincidentes com o bem comum; (iii) que a ação realizada possa constituir-se como uma forma de ação moral ideal, de modo que o que eu realizo possa também ser uma lei universal em sentido kantiano para os outros.

Se a minha ação consciente for capaz de satisfazer estas três exigências, será uma ação consciente. Por outro lado, uma ação livre, cuja concepção de liberdade resida apenas na precária concepção de "ausência de obstáculos”, o que é evidentemente um princípio social importante, mas não o único, então a ação realizada não poderá ser tomada como um topos, um modelo de ação.

A diferença entre um caso e outro é significativa. No primeiro caso (freedom), uma nuvem epistêmica cobre as fronteiras entre o poder civil e a consciência, impedindo um diagnóstico mais claro sobre quais os limites reais ao poder político e qual a dimensão intransponível do EU que rejeita invasão externa. No segundo (liberty), há uma escala conceitual mais rica, na qual os vocábulos políticos denotam com maior precisão o que está em jogo.

Entre as aparências e a realidade, entre o jogo das opiniões e a moção intelectual do espírito humano, subsistem dois mundos projetivos: o mundo interior, que começa na liberdade de agir e migra para a liberdade de ter condições de agir; e o mundo exterior, que parte da liberdade de ter condições para agir e dirige-se para a liberdade de agir. Entre a deliberação e a decisão (ponto de vista interno e externo), reside o juízo prático, um ato operativo do intelecto, e a consciência, um ato mental destinado a avaliar o passado, o presente e o futuro de um ser humano relativamente ao que fez e o que deverá fazer, com base em fins e meios específicos. 


\section{A forma básica do bem comum}

A tensão verificada entre a consciência e o poder político exige resposta para uma pergunta fundamental: há um vínculo moral verdadeiro entre a consciência e o poder político, ou seja, há uma forma autêntica de agir politicamente, que encontra sintonia com a natureza da consciência?

A pergunta acima nos leva a constatar se existe ou não uma verdade prática ínsita à atividade política, que nos permita julgar uma conduta social como adequada, ou de forma mais radical, que justifique uma objeção de consciência ou uma obrigação política. Ou melhor, se por trás das variadas cosmovisões que sustentam as ações e expectativas dos agentes políticos, subsiste alguma finalidade auto evidente que aporte para o horizonte de cada um destes mesmos atores uma plataforma de requerimentos práticos compartilhados.

Há uma relação complexa entre o poder político e sua correspondência moral. O vínculo entre o poder e o ethos se determina pelo nexo entre o que compartilhamos e as formas de racionalidade que projetam as nossas ações em cenários diversos e indeterminados. Nossa incapacidade para antever os acontecimentos, os futuros contingentes, é aliviada por medidas estatais e corporativas que nos impelem a absorver certos dispositivos e adotá-los em nossas práticas sociais, frente a necessidade artificial de sopesar o futuro desconhecido com medidas que buscam rastrear os futuros sociais contingentes, por intermédio da previsão e da gestão de risco. Mesmo ante uma constatação empiricamente verificável como esta, a pergunta persiste: há algum bem, ou alguns bens, que alcançamos pelo intelecto e que formatam o que somos, como agimos, por que agimos e como as nossas ações são compreendidas pelos outros? O mero sentido que lançamos sobre o que realizamos basta para explicitar o motivo real e profundo, a razão de ser de nossas ações em sintonia com a forma de existência que perseguimos de um modo mais profundamente engajado?

Somos capazes de entender o porquê alguns de nós agem de um modo $x$ e, por vezes, compreender o sentido da mesma ação. Por que somos capazes para tal? A área turva que caracteriza a epistemologia profunda e a ética normativa, disciplinas inevitavelmente engajadas em discernir o que está no background do que compartilhamos e, além disso, do motivo pelo qual compartilhamos, não pode - sem comprometer a própria estatura científica das disciplinas mencionadas - negar a evidência de certas definições. Afirmar que realizamos certas ações exige, como complemento, que ofertemos alguma resposta sobre o motivo destas ações. Perguntar sobre a razãa para ação é reivindicar o propósito, a causa que originou o ato. Esta reivindicação não é algo trivial, embora a pergunta seja pautada na evidência de que uma ação só pode ocorrer quando há um fim, uma meta, um objetivo em jogo. 
No mundo compartilhado há ações as mais díspares, e objetivos igualmente diversos, mas subsiste em toda esta complexa rede de atos e abstenções a imprescindibilidade do fim.

Quando agimos politicamente, o fazemos não somente pelo motivo de que o que queremos ou não queremos poderá representar a expansão ou a retenção do que podemos dizer sobre o que todos podem ou devem fazer, mas principalmente porque quando decidimos coletivamente devemos apresentar razões sobre estas decisões, elucidando os motivos por meio dos quais os outros deverão agir ou abster-se de agir em certas circunstâncias.

O nível de compartilhamento da matéria da decisão, de aceitação pública dependerá, assim, da satisfação de três requisitos: (i) o compartilhamento real da matéria da decisão, de modo que todos sejam impactados de algum modo; (ii) que a matéria em questão deverá ser objetivamente comunicada, para que todos os envolvidos tenham ciência efetiva e possam, assim, pautar suas ações particulares a partir desta matéria comum; (iii) que a aceitação geral dependerá da maximização da utilidade compartilhada, de maneira que todos estejam engajados em sacrifícios e vantagens igualmente compartidas.

Se, e somente se estas exigências forem satisfatórias em uma comunidade humana, então será possível intitulá-la uma comunidade política. O que a define assim não é apenas o conjunto das instituições que tornam esta comunidade autossuficiente, mas porque esta autossuficiência é baseada em um modo compartilhado de vida comum, em que alguns bens são aquinhoados materialmente e outros bens são evidentemente coparticipados de modo inteligível.

Usemos uma expressão para englobar estes bens básicos compartidos segundo um grau de evidência: bem comum. O bem da comunidade política é o que a torna "política", autossuficiente e objetivamente constituída. Ser ciente de si é reconhecer que sua própria existência está ancorada no que lhe permite ser, existir e subsistir. $O$ bem comum confere a uma comunidade a condição de existência, a ontologia política e a ordenação das relações internas entre os seus membros, pois informa a conjuntura das formas de vida e preenche de sentido as ações livres, ações que dependem de deliberação responsável, de freios e estímulos, limites e solicitudes para o compartilhamento dos resultados e das consequências das ações publicamente verificáveis.

Tomás de Aquino aduz que o bem comum corresponde

... a virtude com que governa o governante político da cidade é como o arquiteto com relação às virtudes dos demais cidadãos, posto que as demais virtudes civis se ordenam à esta, assim como a cavalaria e a arquearia se ordenam à ordem militar. Assim, sendo a virtude suprema, em sua operação consiste a 
felicidade política, como parece indicar o Filósofo (...). Pois na política sucede o mesmo quando é verdadeira e perfeita, que com o corpo bem disposto, no qual todas as forças orgânicas conservam seu vigor. E assim, se a razão, que é a virtude suprema, dirige todas as potencias inferiores e às move com seu império, então haverá suavidade e deleite perfeitos em todas as forças, e é justamente isso que chamamos de harmonia. ${ }^{3}$

O bem comum é a expressão da concórdia política, a forma básica da vida social que desponta como a dimensão metafísica do ente relativamente à faculdade humana da vontade. O bem é apetecível. Logo, o bem comum é o fim compartilhado pelos habitantes da cidade. No bem comum, todos realizam ações autenticamente compartilhadas, engajadas em práticas que resultam no florescimento de todo o corpo político e do próprio agente individualmente considerado.

Entre o bem comum e o bem particular não há uma diferença substantiva, o que não significa dizer que ocorra a mesma situação quando falamos em bens sociais e os bens privados: bem comum e bem particular não correspondem a diferença substancial entre bens irredutivelmente sociais e bens inevitavelmente privados. O bem particular será de fato um "bem" quando contiver, em seu aspecto teleológico e predicativo, uma harmonia proporcional com o bem comum. Ambos convergem para a felicidade da pólis. A distinção é de grau e âmbito de realização. No bem comum, a totalidade dos seres humanos é direta ou indiretamente atingida, enquanto o bem particular implica no florescimento humano do agente que empreendeu a ação que o realizou. $O$ agente que realiza um bem particular converge com o corpo social porque realiza, em seu âmbito próprio de existência, o bem compartilhado. Ao florescer, contribui para o florescimento da comunidade total.

O bem comum é expressão política da utilidade social, tomado como um conceito transcendental, e igualmente como causa final do agir práticomoral. A lei natural, cujo primeiro preceito expressa que um agente humano deve perseguir o bem e evitar o mal, proposição evidente por si mesma, pode ser vista como o princípio extrínseco dos atos humanos que ordena o ser humano a agir em conformidade com o bem, tomando a matéria e o objeto da ação como regra e medida. Diz Tomás de Aquino que

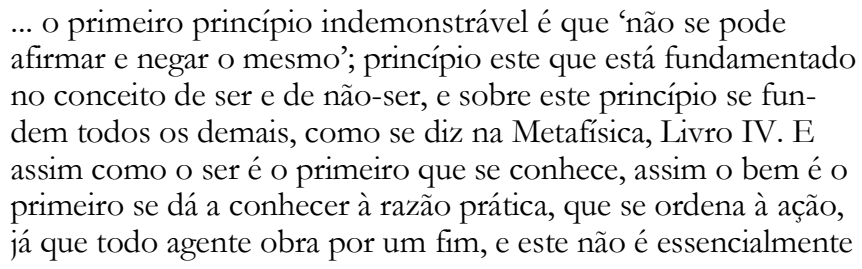

${ }^{3}$ Tomás de Aquino, Gobierno de los Príncipes, $1^{\mathrm{a}}$ ed. (Buenos Aires: Editorial Porrúa, 2008), p. 508. 
senão o bem. E assim, o primeiro princípio da razão prática é o que se funda sobre a noção de bem, que é a seguinte: 'bem é aquilo que a todos apetece'. Este é, pois, o primeiro preceito da lei: que deve fazer-se o bem e se evitar o mal. E sobre este preceito se fundam todos os demais da lei natural: ou seja, que tudo aquilo que se deve fazer ou evitar se submete aos preceitos da lei natural enquanto a razão prática pode captar que tais atos são bens humanos. E como o bem pertence à essência do fim, o mal pertence a todo o contrário; por isso, tudo aquilo para o qual o homem tem uma inclinação natural a razão o capta como bom e, portanto, como algo que deve lograr com sua ação e, ao contrário, capta o mal e como se deve evitá-lo. Assim pois, segundo a ordem das inclinações naturais, há também uma ordem dos preceitos da lei natural. Pois se dá em primeiro lugar uma inclinação do homem ao bem, naquilo que possui de comum com os outros seres humanos; e assim, com todos eles, tende a conservação de si mesmo, segundo sua natureza (...). E finalmente se dá no homem uma inclinação ao bem segundo a natureza racional que lhe é própria; e de acordo com ela, o homem tem inclinação natural a conhecer a verdade sobre Deus e a viver em sociedade. ${ }^{4}$

A razão prática, operação intelectual própria do intelecto prático, que capta o bem como fim para a agência e conduz o agente a deliberar bem sobre as circunstâncias do ato e sobre os meios adequados para a realização do fim perseguido, toma o bem como seu telos. O aperfeiçoamento da operação intelectual que amplia a capacidade deliberativa do raciocínio prático, mediante maior esclarecimento das proposições práticas inferidas dos primeiros princípios da razão prática, tomados como análogos aos preceitos da lei natural, depende de uma virtude própria do intelecto prático, capaz de aperfeiçoar a deliberação racional. Trata-se da prudência. A phronesis, uma virtude do intelecto voltada para aperfeiçoar a racionalidade prática, é condição e semente para as demais virtudes morais, como a coragem e a temperança. Notadamente aqui, a prudência implica na recta ratio agibilium, na reta razão de agir, que conduz a agente a realizar o bem na própria atividade que realiza.

Esta forma básica do bem que é perseguida nas ações e provoca o modelo da agência, a ação entendida como topos, como padrão objetivo do agir moral, articula-se com a ontologia da política na medida em que a predicabilidade do bem nas ações variadas dos seres humanos supõe uma variação analógica nos graus e nos tipos de realização do bem nas diferentes circunstancias.

A indústria racional dos atos humanos requer, para sua comunicabilidade, que a comunidade possa entender e compreender as ações compartilhadas. Uma ação boa não só resulta no bem particular do agente, mas causa o bem dos demais porque as consequências deste ato irão afetar uma quanti-

4 Tomás de Aquino, Suma de Teologia I-II: q.94. $1^{\mathrm{a}}$ ed. (Madrid: BAC, 1955), p. 128 e ss. 
dade indeterminada de pessoas. As ações politicamente relevantes o são porque os resultados que perseguem afetam a vida de contingentes indeterminados de seres humanos. A política é uma instância de forte relevância para a sociedade e para a vida humana como um todo porque as decisões ali produzidas trazem efeitos incontestes sobre toda a comunidade. Logo, a forma básica do bem, mais do que a mera vontade geral ou mesmo do que a vontade da maioria, é a tipologia teleológica que, de fato, explica com maior realismo o que e para que existe o fenômeno político. Mais do que a mera vontade, a razão é solicitada a operar quando tratamos de assuntos públicos.

A prudência política consiste em orientar o exercício das demais virtudes na comunidade humana, presidindo a vontade e dirigindo a inteligência para o bem agir. Decidir sobre o bem concreto e particular de uma situação política pressupõe que o agente possua não apenas o ânimo de decidir retamente, senão também uma disposição para "saber" decidir de modo reto. ${ }^{5}$ Implica, assim, um agir, uma imersão circunstancial do governante na realidade social. A decisão política requer uma deliberação sobre os meios para se alcançar os bens humanos, isto é, uma seleção determinada por um juízo prático sobre quais são os bens humanos publicamente compartilháveis e aplicáveis a certas circunstâncias que exigem uma solução capaz de ordenar os atos individuais em prol da comunidade completa. O desafio do governo político não está em maximizar o próprio poder ou instaurar o temor como arma, mas em discernir retamente os meios para decidir em virtude do bem comum. Entre a deliberação e a decisão, desponta a tarefa pedagógica da razão prática, do aperfeiçoamento dos métodos e operações, como também da virtude e da cognição de seus fins.

$\mathrm{O}$ ato de decisão exige um juízo deliberativo sobre a ação concreta. Do governante se exige a prudência - recta ratio agibilium, disposição racional dos meios adequados para a ação. A prudência política consistirá em um ato da razão prática que determina politicamente a disposição dos meios adequados para a concreção do bem comum e, assim, de um ato de decisão racional em conformidade com a reta razão. A prudência educa o agente

\footnotetext{
5 Josef Pieper, Tratado sobre las Virtudes: I- Virtudes Cardinales, $1^{\mathrm{a}}$ ed (Buenos Aires: Librería Córdoba, 2008), p. 20. Diz Pieper: "La primera de las virtudes cardinales es la virtud de la prudencia. Más aún, la prudencia no es sólo la primera entre virtudes de igual rango: ella 'engendra' todas las virtudes Morales. Esta afirmación de la primacía de la prudencia, que apenas somos capaces de comprender en su verdadero significado, implica algo más que un orden más o menos casual entre las virtudes cardinales. Transcribe, en el campo de lo ético, la constitución fundamental de la realidad: el bien supone la verdad, y la verdad supone el ser. ?Pero qué significa en quanto a su contenido la primacía de la prudencia? No otra cosa que lo siguiente: la realización del bien presupone el conocimiento de la realidad. Lo primero que se espera de quien obra es que sepa, dice Tomás. Quien no sabe cómo son realmente las cosas tampoco puede obrar el bien, porque el bien es lo conforme a la realidad (...). Por la prudencia el conocimiento objetivo de lo real se transforma en la medida de la acción. El prudente dirige su mirada por una parte a la realidad objetiva de las cosas $y$, por otra, al querer y al obrar".
} 
político para saber como se deve agir e o que deve evitar. A prudência é como diziam os clássicos, auriga virtutum. $\mathrm{Na}$ ordem intelectiva, é virtude cognoscitiva; na ordem prática, hábito moral. Dela, decorrem todas as virtudes morais, que com ela convergem no fim. A prudência determina a conformidade entre a ação prático-moral e o fim captado pela razão, o que implica na adequada deliberação dos meios e a disposição reta para o bem. Por ela, a vontade e os sentidos são governados e educados pela razão, de maneira a perseguir o bem e evitar o mal nas circunstâncias concretas. A prudência capacita o agente para agir bem e determinar, retamente, todas as coisas de forma proporcional.

O intelecto, faculdade mais nobre do ser humano, matriz com distintas dimensões e funções, toma como suas finalidades o conbecimento da verdade e do bem. O intelecto-nous- e a razão-dianoia- se distinguem no seguinte sentido: enquanto o intelecto é capaz de todas as coisas -capax omnium-, para falar com Aristóteles, a razão invoca o saber demonstrativo e argumentativo, próprio do campo científico, e depende sempre dos primeiros princípios, que são "notados" pelo intelecto como evidentes e indemonstráveis. A dianoia trata dos juízos demonstrativos próprios das ciências e dos universais; porém, demanda uma justificativa anterior e causal que lhe atribua consistência epistêmica: a nous. Como afirma Juan Cruz Cruz, "el primerprincipio, al cual se orienta el nous, tiene naturaleza incondicionada, y es alcanzado no discursivamente, sino por inmediatez cognoscitiva, tanto subjetiva, como objetivamente"6. A intelecção imediata dos princípios evidentes elucida as condições de possibilidade lógicopredicativas dos juízos e das demonstrações.

A razão prática, racionalidade própria do agir, toma o bem como fim porque a inteligência prática o infere como um princípio evidente, como o postulado de onde decorrem os raciocínios práticos e as ações compartilhadas entre os seres humanos. A antiga tensão entre suposição e principiação, típica da visão tomista sobre a diferença entre razão e intelecto, leva-nos a afirmar, junto com Cruz Cruz que se "el criterio de verdad viene dado no en la acción discursiva de la razón, sino en la contemplación de las cosas por el intelecto", então é inegável que a intelecção do bem próprio da comunidade civil pressupõe o limite real entre o ato de decisão e a vida privada, entre o que é próprio da pólis e o que pertence ao oikos (administração doméstica).

Dentro disso, é notório que a natureza racional do ser humano implica tomar o bem comum como o objeto da ação e primeiro princípio da racionalidade prática política, cujo hábito moral dirige o agir para a sua forma básica correspondente. O conhecimento da forma básica do bem político

6 Juan Cruz Cruz, Intelecto y Razon: las coordenadas del pensamiento según Santo Tomás, 3 ed. (Pamplona: EUNSA, 2009), p. 17.

${ }^{7}$ Ibid., p. 21. 
acarreta para o governante as seguintes exigências: (i) ter ciência do bem, a partir da constatação intelectual de que o bem é um princípio evidente: o bem deve ser perseguido e o mal evitado; (ii) agir de modo a persegui-lo nas deliberações sobre os meios adequados em circunstâncias que impliquem consequências irradiadas para toda a coletividade; (iii) saber distinguir o que é evidente do que é apenas provável ou verossímil, de forma a separar o que está no campo da verdade prática (bem) - apoiada em princípios evidentes - e o que reside no campo das ideologias e opiniões particulares; (iv) agir em conformidade com o bem comum, distinguindo o que pertence à pólis e o que é próprio do âmbito privado; (v) agir de forma a conservar a harmônica relação entre os bens sociais e os bens privados, convergindo em suas decisões para a adequada separação entre o público e o privado, reconhecendo que há bens inevitavelmente privados e bens irredutivelmente sociais.

Dentre os bens inevitavelmente privados, reside a complexa rede das faculdades humanas, temática enfrentada no âmbito da antropologia filosófica, e do que anteriormente salientamos como liberdade para ter condições de agir e liberdade de agir, além das liberdades fundamentais e dos direitos civis. Obviamente, o reconhecimento do que é público e do que é privado requer que os bens compartilhados sejam igualmente percebidos por toda a coletividade, mas dependem, sobretudo, da autoridade da faculdade intelectual para serem explicitamente postulados como uma reivindicação de caráter universal. O estatuto de universalidade do bem comum não está sustentado na opressão do público sobre o privado, ou vice-versa, mas justamente na proporcionalidade entre o que é irredutivelmente social e o que é inevitavelmente privado. Sem, portanto, o recurso ao bem comum como fator judicativo, como ponto de encontro entre a esfera pública e a esfera privada, não será possível vislumbrar os limites constitutivos entre o que é próprio do social e o que pertence ao individual. No que é mais irredutível em cada uma das esferas, é perceptível a radicalidade da diferença proposta, mas quando aproximamos a ambas, as distinções fortes vão cedendo para dar lugar à evidência da fronteira: o limite que distingue uma e outra. Nos polos radicais, encontramos de um lado o poder, e de outro a consciência.

\section{Consciência}

A consciência é tema complexo. Na história da filosofia, há uma plêiade de denotações admitidas para esta expressão, que moldaram diferentes sistemas filosóficos e teorias sociais que lhes são decorrentes. Normalmente, o estabelecimento da palavra no interior de esquemas especulativos profundos costuma explicitar o enquadramento da consciência não pelo que ela de fato é, mas como algo que é articulado de fora e que possui relação com o miolo central do sistema em questão, a saber, com o que é afirmado como 
objeto do conhecimento: como a coisa de que se tem consciência. Em outros casos, a consciência é vista de um ponto de vista funcional: como algo correlato a potência pela qual somos conscientes.

Rigorosamente, consciência não é nem hábito nem potência. Segundo Tomás de Aquino, a palavra consciência não é nem potência nem hábito, mas um ato. Somente quando coincidem com este ato, potência e hábito possuem alguma relevância semântica para o tema em questão. Via de regra, um ato é próprio de alguma potência ou de algum hábito. Quando tratamos da consciência, assumimos que estamos a tratar de um ato mental, um ato que é gerado porque pressupõe hábitos e potências para a sua consumação. Na questão sobre a consciência, presente nos Opúsculos, Tomás nos diz que

consciência significa a aplicação da ciência a algo: se diz com saber como saber conjuntamente - ...unde conscire dicitur quase simul scire -. Toda ciência pode aplicar-se a algo. E, assim, a consciência não pode significar nenhum hábito ou potência especiais; significa o ato mesmo, que é a aplicação de qualquer hábito ou de qualquer conhecimento a um ato particular. ${ }^{8}$

Consciência, portanto, é um ato mental. Um ato que é fruto da aplicação de algo anterior, um hábito ou um conhecimento. O mesmo Tomás no diz um conbecimento se aplica a um ato de três modos:

(i) de acordo com a consideração sobre o que o ato é ou foi;

(ii) mediante o hábito da ciência, nos dirige a fazer ou abster-se de fazer algo;

(iii) quando já executado o ato, julgamos se o ato é reto ou não é reto segundo o hábito da ciência. ${ }^{9}$

No primeiro caso, temos consciência de um ato quando ele foi realizado ou não foi. Neste caso, estamos diante de um fato pretérito, e a memória é requerida para a ciência do acontecimento. Tomás diz que esta é uma aplicação a um ato particular do conhecimento sensitivo: da memória por meio da qual recordamos o que foi feito.

No segundo caso, estamos a tratar de uma ação a ser realizada. O conhecimento prático é movido ao futuro contingente em que a ação será empreendida ou não será realizada. Neste segundo caso, assim como o terceiro pertencente ao âmbito especulativo, tratamos de uma operação em que, mediante a ciência, o agente busca, mediante conselho, o que há de ser feito ou evitado. É, segundo o Aquinate, "semelhante à invenção pela qual, desde

8 Tomás de Aquino, Opúsculos y cuestiones selectas II: Cuestiones de la syndéresis y la consciencia, $1^{\mathrm{a}}$ ed. (Madrid: 2003), p. 266.

${ }^{9}$ Ibid., p. 267. 
os princípios, investigamos as conclusões (...). quando a consciência se aplica ao ato para dirigi-lo, se dir que a ciência o instiga, o induz ou o obriga"10.

No último caso, a consciência move o agente a examinar o que foi feito, segundo uma razão de bem. O hábito intelectual dos primeiros princípios práticos (sindéresis) move o agente a avaliar tanto o que deve realizar segundo uma forma básica de bem (segundo caso), como também o permite avaliar se o que realizou foi ou não foi feito de acordo com os bens humanos. Novamente Tomás é cristalino: "o procedimento pelo qual examinamos ou discutimos se é reto o que realizamos, é análogo ao juizo pelo qual as conclusões se resolvem com base nos princípios (...). Quando a ciência se aplica ao ato para examinar o que se fez, se diz que a consciência acusa ou remorseia" 11 . Neste terceiro caso, a consciência se diz como o conhecimento que é lançado sobre o ato pretérito de modo a julgá-lo segundo a discordância com a ciência dos primeiros princípios práticos, a partir dos quais se julga objetivamente a ação. Defender ou escusar, acusar ou justificar, são alternativas que dependem deste caso, pois o que avalia o próprio ato ou algum ato alheio, o faz tendo por base a forma da ciência prática, em atinência a forma básica da ação humana realizada.

Como se vê, a consciência é um ato mental complexo e reflexo, ao mesmo tempo em que solicita da memória e do intelecto uma participação, também o faz quanto ao hábito intelectual e as virtudes intelectuais e morais. Especialmente nos dois últimos casos, onde refletimos sobre o que há de ser feito ou examinamos o que foi realizado, nos diz o autor que

$$
\begin{aligned}
& \text { se aplicam ao ato os hábitos da razão operativa, ou seja, o há- } \\
& \text { bito da sindéresis, e o hábito da sabedoria na qual a razão su- } \\
& \text { perior alcança sua perfeição; e o hábito da ciência no que al- } \\
& \text { cança sua perfeição a razão inferior, se apliquem todos eles de } \\
& \text { uma só vez ou somente um deles por vez. Segundo estes hábi- } \\
& \text { tos examinamos o que realizamos e segundo eles refletimos } \\
& \text { sobre o que temos de fazer. O exame não é somente do fato, } \\
& \text { senão também do que se há de fazer; o conselho, todavia, é } \\
& \text { somente atribuído ao que se deve fazer. }
\end{aligned}
$$

Como vimos, a consciência envolve uma lista de atos mentais. Em todos eles, as potências humanas, os hábitos intelectuais e práticos, a ciência de certos princípios evidentes, como também a forma básica dos bens humanos constituem-se como peças fundamentais no arranjo dos atos humanos. Agir supõe fazê-lo sob a guarida da consciência.

No âmbito da vida social, a consciência desempenha uma função de alta monta. A partir dela colhemos os conselhos, os remorsos, os julgamen-

\footnotetext{
10 Idem.

11 Idem.

12 Idem.
} 
tos e, em grande medida, as previsões sobre os nossos atos. Agir socialmente requer um esforço interior por projetar uma determinada modalidade de ação sobre a qual recaem diversos eventos e atos mentais: do sentido comum e da imaginação, para a memória sensitiva e os hábitos operativos, a ciência dos princípios da ordem prático-moral, os fins e os meios que constituem a ação como tal, até a imagem de ação que podemos projetar no horizonte da vida compartilhada, como a avaliação que fazemos quanto ao impacto que uma ação conscientemente coletiva pode gerar nos afetos e nas emoções dos outros.

Ter uma consciência é, assim, ser dotado de um ato mental fortemente relevante para ver forjada uma identidade social significativa.

No mundo público, a política requer, de parte daqueles que a exercem, uma consciência especial. Dado que pertence ao espaço do governo decidir, incumbe ao ato de decisão um background: um pano de fundo, em que diversos sentidos são involucrados no ato isoladamente considerado. A consciência ou inconsciência destes sentidos é algo que fortalece ou enfraquece não somente a qualidade da decisão, mas sobretudo a real participação de quem a toma em seu âmbito semântico.

Enquanto o ato de decisão for reto, a consciência particular dos membros da comunidade estará salvaguardada pela ordem e, assim, pela correspondência entre a verdade prática (bem) e a realidade política. Logo, um ato de decisão publicamente autêntico será aquele no qual a consciência do governante que decide e as consciências dos membros da comunidade estejam em sintonia analógica quanto à identidade da forma básica do bem: um bem compartilhado; um bem que, não obstante as diferentes percepções inteligíveis que possa sofrer, conserva-se impávido ante a pluralidade das opiniões. A evidência do bem em questão pode ser mais ou menos extensa; de qualquer modo, o reconhecimento e a aceitação de um mínimo grau objetivo de captação intelectual acerca do bem como tal é algo intransponível não apenas para a legitimidade de toda e qualquer decisão em matéria social, mas especialmente significativo para que qualquer consciência possa julgar ou aconselhar, de forma objetiva, se um ato humano foi adequado ou se a ação a ser realizada deverá perseguir o bem de acordo com um meio ou outro.

\section{Poder e consciência}

É próprio do poder a expansão. Como fenômeno complexo e crescente, o poder tende ao alargamento gradativo. Qual, então, o limite intransponível para o poder?

Aristóteles chamou sua obra de Política com o intento de demonstrar que todas as cidades são constituídas em virtude de algum bem e que seus 
governos devem tender para a concreção desse fim. Política corresponde à ordenação das relações humanas em geral, supondo o envolvimento dos seres humanos com os bens inevitavelmente privados e irredutivelmente sociais. Parece existir uma oposição entre os bens privados e os bens sociais. Contudo, tal oposição é aparente: na Política, a organização da comunidade pressupõe uma adequada disposição dos espaços para a realização destes bens. O bem comum, que participa nestes dois tipos de bens (os sociais e os privados), o faz porque tanto o mundo privado como o mundo público só são assim caracterizados porque, para além do espaço limítrofe que os redefine na realidade social, irrompe a causa final própria de cada qual. Os seres humanos se movem no âmbito público e o fazem no espaço privado porque possuem a intenção de realizar certos bens, tomados aqui como fins para estas ações. É característica do bem comum, enquanto fim compartilhado, fornecer ao governo e às associações privadas a noção formal da ação adequada, como também do espaço adequado de ação, de maneira que entre o que é inevitável para a vida privada e irredutível para a vida pública subsista o que é harmônico entre elas. Qual, então, é o objeto próprio da política? Dado que a ela cabe a organização segundo a forma básica do bem comum, a política é a expressão material da ordem. A ordem, por sua vez, é a forma propriamente dita do bem comum, o status objetal sobre o qual repousa a política como mecanismo de organização social. A ordem explicita a fronteira e a ponte entre o público e o privado: o limite e o diálogo entre os bens inevitavelmente privados e os bens irredutivelmente sociais.

Política e poder não são a mesma coisa. Poder condiz com o exercício em si da governabilidade sobre as comunidades humanas, tanto no nível de seus acidentes quanto no plano de suas delimitações. Poder é um verbo irregular e um fenômeno complexo. Quando tratamos deste fenômeno soerguem-se três formas de expressão da ação humana: a força, a economia e a manipulação. A força consiste no mando efetivo, no domínio de um agente sobre outrem; a economia pressupõe uma relação de demanda e oferta em que um agente exige uma correspondência após oferecer ao ofertante um bem devido; a manipulação aduz uma relação em que alguém exerce influência sobre outrem. Em todos os casos, fica evidente que poder exige uma relação ou uma expectativa. A categoria de relação exige que, na realidade, coexistam dois ou mais agentes que se interpenetram mutuamente com o fim de atingir certos objetivos correlatos.

O tribunal da história, um mito criado pelo imaginário poético para conferir validação universal ao senso mítico presente na cultura humana e na vocação inexorável para a redenção do sentido da existência, evoca um retrato teleológico para a história: a penetração dos antagonismos históricos 
para dentro do que Pereña Vicente chama de sagrado santuário da consciência ${ }^{13}$, ou seja, um espaço reservado para a decisão individual alheio às ingerências políticas de toda ordem, capaz de justificar, mesmo no terreno teológicopolítico, a rebelião contra a tirania. O decisionismo, traço típico do poder soberano segundo a visão schimittiana da política ${ }^{14}$, esbarra na consciência como o seu oponente inerte, impenetrável e enigmático.

A consciência é impenetrável porque o agente consciente, ao ver-se ameaçado pelo poder, tem a opção de deslocar o centro da autoridade decisória do âmbito externo do governo para o âmbito interno da própria consciência, passando ela - e não mais o poder civil - a reger os seus próprios atos. A consciência é também enigmática porque o agente não demonstra o bem, tampouco os princípios da razão prática que dele decorrem, mas apoia-se nele como um postulado evidente. Logo, o desconhecimento do governo externo frente ao caráter imperativo da consciência pode, quando o exercício do poder não encontra nos limites da ordem uma restrição fortemente aceita, conduzir a desobediência civil.

Os limites da obediência e da obrigação política em um regime político são determinados pelo modo como a forma básica de bem é expressa pela organização da cidade e encarnada pelos governos que a regem. Quando os limites são deteriorados e a legitimidade dos governos cessa, então um novo cenário, uma nova busca da ordem, se torna premente.

Dentre as várias diferenças existentes entre política e poder, acha-se a da consciência. Na política, isto é, na ordem, a consciência opera para aconselhar ou julgar segundo a forma básica do bem perseguido de um modo estável, partindo do que já está posto: os limites entre o público e o privado, assim como as relações que lhes acompanham. No poder, nem sempre, pois se o complexo fenômeno da expansão não restringir-se aos limites mencionados, a estabilidade necessária para a articulação entre o conhecimento e os atos humanos, onde reside a consciência, não poderá ser garantida. O julgamento objetivo de uma consciência individual tenderá a contrastar com os atos de decisão na esfera política, gerando o risco da desobediência civil.

Logo, cabe indagar: o Estado moderno é uma forma de organização do poder civil que conserva o poder dentro da política? A expansão dentro da ordem? Ou por outro lado, em razão de sua estrutura, oferece perigos incontornáveis para a consciência, não sendo capaz de assegurar que o poder sempre terá limites?

${ }^{13}$ Luciano Pereña Vicente e outros, De Iuramento Fidelitatis: Estudio preliminar "Conciencia y politica” - proceso de politizacion europea (1 ${ }^{\text {a }}$ ed. Madrid: CSIC, 1979), p. 21.

14 Carl Schmitt, Romanticismo Politico (Buenos Aires: Universidad Nacional de Quilmes, 2001). 
Frente ao postulado jurídico do que chamaremos de liberdade de consciência, valendo-nos dos diplomas constitucionais contemporâneos, o Estado moderno se edificou nos últimos séculos de acordo com três modalidades: (i) em primeiro lugar, Estados que organizaram suas estruturas institucionais e burocráticas distinguindo de forma rígida os bens sociais e os bens privados, sem nenhuma correspondência entre ambos; (ii) segundo, Estados que estabeleceram mecanismos instrumentais eficientes para articular o público e o privado, inclusive estabelecendo relações entre estas esferas, mas mantendo em cada qual os bens inevitavelmente privados e os bens irredutivelmente sociais; (iii) Estados que não estabeleceram (na prática, a despeito do tratamento dado pelas Constituições políticas) nenhuma fronteira "empiricamente verificável" entre o público e o privado, o que implicou na ausência de qualquer acepção comunicativa dos bens sociais e privados.

Independentemente dos fatores e das causas que levaram a formação destas modalidades estatais, o fato é que cada um dos tipos aludidos trata da "fronteira" de um modo particular, o que resulta, para os propósitos da liberdade de consciência, um tema vital.

O tema da consciência aparece de forma mitigada no primeiro e no segundo tipo, mas não no terceiro, onde a ausência de fronteiras claras provoca a situação de que a falta de limites possa acarretar a desobediência civil.

Quando não há limites, tudo é possível. O governo pode, dentro de um Estado assim (des)organizado, invadir esferas que lhe competem. Há inclusive o risco de que o poder civil possa tornar-se a única fonte da moralidade, um traço típico dos regimes totalitários.

Este problema, o qual chamaremos "jurisdição de consciência”, parte de uma situação hipotética na qual o governo não restringe-se ao exercício do poder civil dentro dos limites institucionais traçados pelo Estado, mas comporta-se segundo o desenho morfológico do terceiro tipo de Estado antes aludido: alarga sua jurisdição para além do campo institucional pré-definido, atingindo os bens compartilhados, não só prevaricando os bens irredutivelmente sociais, mas esfacelando os bens inevitavelmente privados, coagindo a consciência individual a examinar os fatos e avaliar as circunstâncias futuras para as ações em acordo às medidas ilegítimas levadas a cabo pelo próprio governo. A ameaça à consciência provoca normalmente: (i) o temor, (ii) a desobediência civil, (iii) a mentira (contra o Estado) como arma vital.

Agir ou abster-se de agir em um Estado que invade a jurisdição da consciência requer que a razão do agente reivindique, para bem deliberar, o auxílio de outros atributos intelectuais e volitivos, como a previsão, a sagacidade, a expectativa, o risco e a fortaleza física e psíquica, de uma forma mais contundente do que normalmente ocorre em um ambiente de normalidade. 
O estímulo à inimizade, desconfiança, espionagem, falta de padrões, escassez de recursos materiais e egoísmo conduzem o agente a tomar a própria consciência como um recurso cada vez crescente na medida em que o alargamento do poder estatal se faz notar.

A jurisdição da consciência sempre existiu desde que o poder despontou no início da civilização como um fenômeno correlato a existência política da sociedade. Na modernidade, a jurisdição de consciência está diretamente articulada com a estrutura do Estado Nacional Moderno.

O Estado é uma forma de organização do poder típica do Ocidente, que busca, através da despersonalização e da institucionalização do poder, fazer frente às guerras civis e religiosas existentes na Europa. De fato, as guerras religiosas se disseminaram, pelo menos em algum sentido, pelo próprio problema da jurisdição de consciência.

Dentro deste contexto surge o problema da "obrigação de consciência", isto é, do uso do aparato estatal pelos governos para estender um conjunto de exigências infundadas e padrões artificializados para além da ordem política. O objetivo deste alargamento está em obrigar as consciências de modo a parametrizar as relações sociais e redefinir o horizonte de expectativas dos seres humanos.

O uso do poder para jurisdicionar as diferentes consciências, tornandoas ficticiamente "obrigadas" a seguir os novos padrões, foi intensamente aplicado no século XX e tem sido uma tática amplamente empregada por governos e organizações no século XXI. O objetivo aqui não é outro senão tornar a obrigação de consciência um dogma de obediência civil.

O problema da obrigação de consciência é antigo e, na história ocidental, orbita em torno do iuramento fidelitatis. É fato que a tradição medieval dos reis fidelíssimos estava apoiada na ideia de que o juramento é um ato jurídico complexo, em que todas as partes celebram e firmam obrigações recíprocas. O rei jurava fidelidade ao Direito e aos súditos; estes, ao monarca, nos limites estabelecidos pelas fontes consuetudinárias. Tanto os reis como a comunidade civil juravam fidelidade restrita ao pacto firmado por ambos. O pacto simbolizava a associação política, de forma a expressar concretamente a ordem social.

Porém, a história mostra alguns eventos em que os pactos firmados e jurados foram violados por governos impolíticos (tirânicos). Vejamos, a título de exemplo, o caso da Inglaterra de Rei James I. Durante seu reinado, o juramento de fidelidade sofreu nova interpretação. Apoiado no que havia feito sua antecessora, a Rainha Isabel I, James sustentava que o juramento deveria ser entendido como um dever da comunidade civil de reconhecer o monarca como autoridade simultaneamente política e espiritual. Os católi- 
cos ingleses insurgiram-se contra esta medida, postulando a defesa da autoridade espiritual do Papa e o direito de consciência sobre o primado da fé em questões espirituais. A reivindicação que arguiram cingia-se em torno da ilegitimidade do monarca para cumular as duas jurisdições, e a violação da obrigação política empreendida quando, negando-se a respeitar os limites entre as duas espadas, James I coagiu a comunidade católica a aderir a um juramento claramente diverso da forma historicamente admitida no direito comum. Porém, Jaime I insistia em alocar para si essa condição, invocando o direito divino em seu favor, impondo a todos os cidadãos ingleses - católicos e não católicos- a obrigatoriedade de jurar fidelidade ao monarca, inclusive em questões espirituais. O Papa Paulo V, buscando contestar a postulada teoria do direito divino dos reis arguida por James em favor de sua autoridade absoluta, convoca o teólogo Francisco Suarez para oferecer uma resposta ao Rei.

Em 1613, Suarez publica Defensio Fidei catholicae et apostolicae adversus anglicanae sectae errores, fruto da disputa levada a termo contra a tese do monarca inglês e após sucessivas investidas do monarca contra a Santa Sé e a Igreja Católica inglesa. No Livro VI do tratado, faz um diagnóstico exaustivo sobre a natureza jurídica do juramento, seu objeto próprio e os limites que lhes são impostos. Defende o autor que o juramento é devido na forma da lei natural e do direito civil, o que supõe ser imperioso o direito à consciência individual frente às questões de fé e de ordem interna. A "obrigação de consciência" só seria devida à autoridade do rei no plano temporal e nos limites do direito natural e das gentes, expressos no pactum subjectionis firmado entre a monarquia e a sociedade. $\mathrm{O}$ juramento, neste diapasão, encontra uma sólida fundamentação na tradição do direito comum e das fontes medievais e clássicas do Direito no ocidente. Ao rei é vedada a jurisdição sobre a consciência dos "súditos". Sua autoridade é restrita aos limites estabelecidos pelo Direito, dentro do qual o exercício do poder civil é legítimo e de direito natural. ${ }^{15}$

Suarez oferecia, assim, um exame pormenorizado sobre o iuramentum fidelitatis. A consciência e o poder eram colocados em áreas distintas: ao poder, cabia a atenção aos limites e o emprenho na realização do bem comum; à consciência, o conselho e o juízo sobre os próprios atos. A justificativa de fundo da tese suarista estava apoiada na ideia de que a "obrigação de consciência" jamais pode ser imposta por qualquer autoridade, senão dentro dos limites traçados pelo bem comum e expressos pelo direito natural, comum e das gentes.

15 Francisco Suarez, Defensio Fidei VI, $1^{\text {a }}$ ed. (Madrid: CSIC- Corpus Hispanorum de Pace, 1965), p. 33. 
No século XX, os regimes totais postularam novos padrões de justificação para a "obrigação de consciência". A clara visão de mundo que os sustentava estava inteiramente ancorada na ideia de que a consciência deve ser moldada pela ideia perseguida como expressão da verdade política: o governo civil é o mecanismo por meio do qual o mundo deve ser transformado. Neste caso, a "obrigação de consciência" vai sendo, paulatinamente, imposta sem a percepção clara daqueles que estão envolvidos no espaço público deliberativo da ordem política.

A politização da consciência, a extensão de padrões pré-definidos para além da política, atingindo a própria consciência dos indivíduos, é a grande ambição do poder total. A pessoa humana é integrada no Estado não como sujeito de direitos e deveres, mas como parte da máquina estatal, como uma peça na rede sistêmica do poder orgânico. No fundo, o ser humano passa a ser visto dentro de uma perspectiva instrumental, em que o Estado é o fim e a pessoa, o meio para atingi-lo. O poder civil penhora a consciência e confere a ela um novo símbolo, que substitui o bem objetivo, comprometendo a direção futura do conselho e o exame judicativo sobre os atos pretéritos. $\mathrm{O}$ interior do ser humano, sua percepção da realidade e seu sentido de vida são amortizados por uma nova simbologia artificial. 


\section{Referências bibliográficas}

Cruz Cruz, Juan. Intelecto y Razon: las coordenadas del pensamiento según Santo Tomás. $3^{a}$ ed. Pamplona: EUNSA, 2009.

Pereña Vicente, Luciano e outros. De Iuramento Fidelitatis: Estudio preliminar "Conciencia y politica" - proceso de politizacion europea. $1^{\mathrm{a}} \mathrm{ed}$. Madrid: CSIC, 1979.

Pieper, Josef. Tratado sobre las Virtudes: I- Virtudes Cardinales. $1^{\mathrm{a}}$ ed. Buenos Aires: librería córdoba, 2008.

Ricoeur, Paul. O si-mesmo como outro. 1. ed. São Paulo: Martins Fontes, 2014.

Schmitt, Carl. Romanticismo Politico. Buenos Aires: Universidad Nacional de Quilmes, 2001.

Suarez, Francisco. Defensio Fidei VI. $1^{\mathrm{a}}$ ed. Madrid: CSIC- Corpus Hispanorum de Pace, 1965.

Tomás De Aquino. Opúsculos Y Cuestiones Selectas Ii: Cuestiones De La Syndéresis Y La Consciencia. $1^{\text {a }}$ Ed. Madrid: 2003.

_. Gobierno de los Príncipes. $1^{\mathrm{a}}$ ed. Buenos Aires: editorial Porrúa, 2008. . Suma de Teologia I-II: q.94. 1ª ed. Madrid: BAC, 1955. 


\section{Civil Power and The Obligation of Conscience: The Limits of Politics}

ABSTRACT: This paper presents a brief reflection on the limits of civil power in relation to human conscience. To that end, it proposes an articulation between the liberty to have conditions to act and moral-practical action, and this articulation is shown as a standardtypology of practical reason, in addition to being an objective criterion that is sufficiently capable of grounding legitimate political action, as distinct from "impolitical action", here understood as a phenomenon in which power finds no objective limits and expands into spheres that lie outside its purview. The definitive criterion that ascertains political action as anchored in prudence is the common good.

KEYwORDS: Power; Conscience; Saint Thomas Aquinas; Francisco Suarez; Rule of Law 